\title{
Performance analysis of power generation by wood and woody biomass gasification in a downdraft gasifier
}

\author{
Sahar Safarian, Runar Unnthorsson, Christiaan Richter \\ Faculty of Industrial Engineering, Mechanical Engineering and Computer Science, University of Iceland, Iceland
}

\begin{tabular}{l}
\hline Article Info \\
\hline Article history: \\
Received Jun 24, 2020 \\
Revised Oct 14, 2020 \\
Accepted Oct 19, 2020 \\
\hline
\end{tabular}

\section{Keywords:}

Biomass gasification

Power production

Process simulation

Waste to energy

Wood and woody biomass

\begin{abstract}
An equilibrium simulation model was developed by applying Aspen Plus to evaluate the performance of 28 wood and woody biomass (W\&WB) gasification in a downdraft gasifier integrated with power production unit. The developed simulation model does not focus the gasification process as a closed box, it considers important processes in gasification like drying, pyrolysis, combustion, gasification and integrated with power production plant (combustion chamber plus gas turbine). The results for the $28 \mathrm{~W} \& \mathrm{WB}$ alternatives show that the net power produced from 1-ton feedstock entering to the gasification system is between the interval [0-400 kW/ton] and among them, gasification system derived from Tamarack bark biomass significantly outranks all other systems by producing $363 \mathrm{~kW} / \mathrm{ton}$, owing to the favorable results obtained in the performance analysis. Moreover, effect of various operating parameters such as gasification temperature and air to fuel ratio (AFR) on the system performance was carried out. Finally, the developed model is applied as an effective tool to assess the impact of so many biomasses and operating parameters on output power.
\end{abstract}

This is an open access article under the CC BY-SA license.

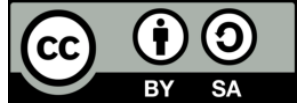

\section{Corresponding Author:}

Sahar Safarian

Faculty of Industrial Engineering, Mechanical Engineering and Computer Science

University of Iceland

Hjardarhagi 6, 107 Reykjavik, Iceland

Email: sas79@hi.is

\section{INTRODUCTION}

The finite nature of fossil fuels, high prices and their negative effects on environment and public health, are encouraging to find renewable energy sources and alternative technologies to produce power [1-3]. Biomass is a renewable energy option that is abundant and can create low net $\mathrm{CO}_{2}$ emission and it has also the greatest potential to substitute for transportation fuels [4-7]. Woody biomass is also one of the important energy sources and it is currently the most important source of renewable energy, globally. In 2010 worldwide use of woody biomass as energy resource was about $3.8 \mathrm{Gm}^{3}$ (30 EJ/year), which consisted of 1.9 Gm3 (16 EJ/year) for household fuel wood and $1.9 \mathrm{Gm}^{3}$ (14 EJ/year) for large-scale industrial sector. During this period, global primary energy consumption and global renewable energy consumption were 541 EJ and 71 EJ, yearly. Hence, in 2010 woody biomass formed roughly $9 \%$ of world primary energy consumption and $65 \%$ of world renewable primary energy consumption $[8,9]$.

Gasification has attracted attention as one of the most efficient methods for utilizing woody biomass, as $\mathrm{CO}_{2}$ emission has become an important global issue [10-14]. Biomass gasification means incomplete combustion of biomass resulting in production of combustible gases consisting of carbon monoxide $(\mathrm{CO})$, hydrogen $\left(\mathrm{H}_{2}\right)$ and traces of methane $\left(\mathrm{CH}_{4}\right)$ [15-20]. This mixture is called syngas. Syngas can be used directly to run internal combustion engines, it can be consumed as substitute for furnace oil for 
heat production and can be used as chemical feedstock to produce methanol [21-25]. Therefore, the development of small-scale, woody biomass gasification is a great social need in a resource-poor country or for regions which are far from the central energy networks and require district heat and power systems [11, $26,27]$. The primary aim of this work is to develop a steady state computer model by using Aspen Plus for performance analysis of 28 wood and woody biomass (W\&WB) gasification in a downdraft gasifier integrated with power production. The objective is to find the most efficient W\&WB for power production. Then as a sensitivity analysis we examine the effect of operating parameters of temperature and air to fuel ratio (ARF) to know where the overall system is optimal to reach the maximum net output power.

\section{MATERIAL AND METHODS}

A simulation model relied on equilibrium approach is developed for wood and woody biomasses (W\&WB) gasification linked with power generation plant by employing Aspen Plus. In order to compute physical properties of the components in the gasification, equation of state of PR-BM, Penge RobinsonBoston-Mathias alpha is applied. In addition, for modeling of enthalpy and density of biomass and ash as non-conventional materials, HCOALGEN and DCOALIGT models are used. It is worth to say that MCINCPSD stream includes 3 streams of MIXED, NCPSD \& CIPSD classes, to define the biomass structure and ash streams that are not in Aspen Plus database [12, 28-33]. Figure 1 shows the flow chart of the system simulated in Aspen Plus. The feedstock stream has been described as a nonconventional material and it was defined by determination of the elemental and proximate analysis of feedstock. In order to have a detailed study, $28 \mathrm{~W} \& \mathrm{WB}$ were considered as feedstock for gasifier. Table 1 shows the proximate and elemental analyses of all these feedstocks [34-49]. Temperature through the drying is around $150{ }^{\circ} \mathrm{C}$ to reduce moisture of the original biomass to less than $5 \mathrm{wt} \%$. This step is done by utilizing a RSTOIC, stoichiometric reactor in Aspen Plus. RSTOIC module is practical for chemical reactions with known stoichiometry [50-51].

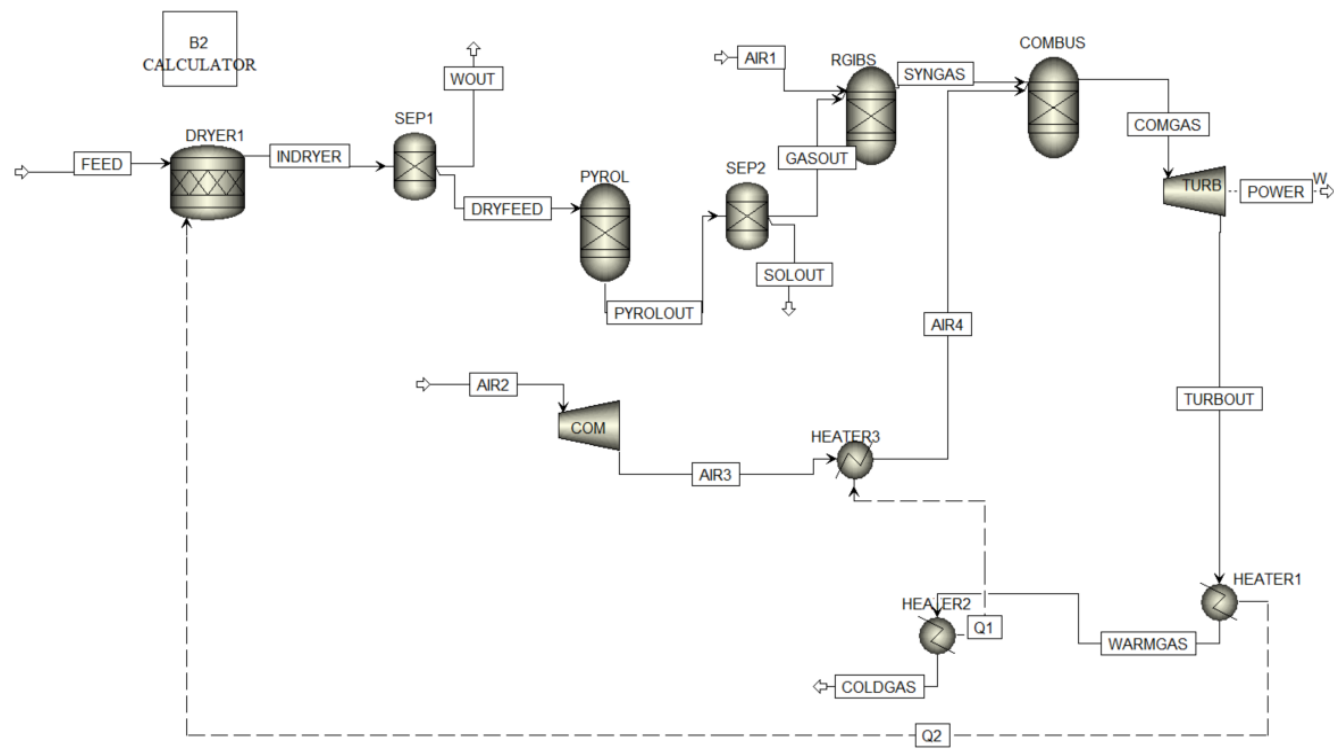

Figure 1. Modules and streams of gasification simulated in Aspen Plus

At the next stage, RYIELD, the yield reactor is simulated for feed pyrolysis. In this part, the studied biomass is transformed to volatile materials (VM) and char. VM includes mainly carbon, hydrogen, oxygen and nitrogen. Char also includes ash and carbon [12, 52-56]. After pyrolysis, RGibbs is applied for simulation of the biomass gasification. This reactor computes the syngas composition by minimizing the Gibbs free energy based on complete chemical equilibrium assumption [57-61]. Input streams to the RGibbs are decomposed biomass and air then combustion and reduction reactions will be occurred inside of the reactor. For combustion level, another RGibbs reactor needs to be simulated with minimum air mixing. This process will be also based on minimization of Gibbs free energy. To generate power, the combustion chamber has to be connected with a gas turbine [62-66]. The thermal content of the flue gas, achived as the combustion heat is recovered to preheat the input air to the combustion chamber as well as to supply the heat required in dryer. The recovered heat can be also utilized for convertion of water to high pressure steam to be

Performance analysis of power generation by wood and woody biomass gasification... (Sahar Safarian) 
able generates extra power by steam driving a steam turbine [40, 41] (this part was not considered in this study). The solid lines and the dashed lines in the Figure 1 present the mass streams and heat streams, respectively. The system is also assumed to be auto-thermal that means a part of the feedstocks is combusted inside the gasifier to provide the heat required in situ. Heat is also obtained by the hot syngas and the combustion chamber then it is consumed wherever required.

Table 1. Elemental and proximate analysis of 28 wood and woody biomasses [20-35]

\begin{tabular}{|c|c|c|c|c|c|c|c|c|c|c|}
\hline & & \multicolumn{4}{|c|}{ Proximate analysis (wt $\%)$} & \multicolumn{5}{|c|}{ Elemental analysis (wt\%- dry basis) } \\
\hline & & M & VM & FC & A & $\mathrm{C}$ & $\mathrm{O}$ & $\mathrm{H}$ & $\mathrm{N}$ & $\mathrm{S}$ \\
\hline 1 & Alder-fir sawdust & 52,6 & 76,6 & 19,2 & 4,2 & 50,9656 & 38,5116 & 5,8438 & 0,479 & 0 \\
\hline 2 & Balsam bark & 8,4 & 77,4 & 20 & 2,6 & 52,596 & 38,473 & 6,0388 & 0,1948 & 0,0974 \\
\hline 3 & Beech bark & 8,4 & 73,7 & 18,5 & 7,8 & 47,3908 & 38,5396 & 5,532 & 0,6454 & 0,0922 \\
\hline 4 & Birch bark & 8,4 & 78,5 & 19,4 & 2,1 & 55,803 & 34,9503 & 6,5593 & 0,4895 & 0,0979 \\
\hline 5 & Christmas trees & 37,8 & 74,2 & 20,7 & 5,1 & 51,7205 & 36,7263 & 5,5991 & 0,4745 & 0,3796 \\
\hline 6 & Elm bark & 8,4 & 73,1 & 18,8 & 8,1 & 46,7771 & 39,0575 & 5,3302 & 0,6433 & 0,0919 \\
\hline 7 & Eucalyptus bark & 12 & 78 & 17,2 & 4,8 & 46,3624 & 43,1256 & 5,4264 & 0,2856 & 0 \\
\hline 8 & Fir mill residue & 62,9 & 82 & 17,5 & 0,5 & 51,143 & 42,2875 & 5,97 & 0,0995 & 0 \\
\hline 9 & Forest residue & 56,8 & 79,9 & 16,9 & 3,2 & 51,0136 & 39,7848 & 5,2272 & 0,6776 & 0,0968 \\
\hline 10 & Hemlock bark & 8,4 & 72 & 25,5 & 2,5 & 53,625 & 37,83 & 5,7525 & 0,195 & 0,0975 \\
\hline 11 & Land clearing wood & 49,2 & 69,7 & 13,8 & 16,5 & 42,3345 & 35,738 & 5,01 & 0,334 & 0,0835 \\
\hline 12 & Maple bark & 8,4 & 76,6 & 19,4 & 4 & 49,92 & 39,648 & 5,952 & 0,384 & 0,096 \\
\hline 13 & Oak sawdust & 11,5 & 86,3 & 13,4 & 0,3 & 49,9497 & 43,7683 & 5,8823 & 0,0997 & 0 \\
\hline 14 & Oak & 6,5 & 78,1 & 21,4 & 0,5 & 50,347 & 42,6855 & 6,0695 & 0,2985 & 0,0 \\
\hline 15 & Olive wood & 6,6 & 79,6 & 17,2 & 3,2 & 47,432 & 43,4632 & 5,2272 & 0,6776 & 0 \\
\hline 16 & Pine bark & 4,7 & 73,7 & 24,4 & 1,9 & 52,7778 & 39,1419 & 5,7879 & 0,2943 & 0,0981 \\
\hline 17 & Pine chips & 7,6 & 72,4 & 21,6 & 6 & 49,632 & 38,07 & 5,734 & 0,47 & 0,094 \\
\hline 18 & Pine pruning & 47,4 & 82,2 & 15,1 & 2,7 & 50,4987 & 40,1849 & 6,1299 & 0,4865 & 0 \\
\hline 19 & Pine sawdust & 15,3 & 83,1 & 16,8 & 0,1 & 50,949 & 42,8571 & 5,994 & 0,0999 & 0 \\
\hline 20 & Poplar & 6,8 & 85,6 & 12,3 & 2,1 & 50,5164 & 40,8243 & 5,9719 & 0,5874 & 0 \\
\hline 21 & Poplar ba & 8,4 & 80,3 & 17,5 & 2,2 & 52,4208 & 38,4354 & 6,5526 & 0,2934 & 0,0978 \\
\hline 22 & Sawdust & 34,9 & 84,6 & 14,3 & 1,1 & 49,2522 & 43,2193 & 5,934 & 0,4945 & 0 \\
\hline 23 & Spruce bark & 8,4 & 73,4 & 23,4 & 3,2 & 51,8848 & 38,72 & 6,0016 & 0,0968 & 0,0968 \\
\hline 24 & Spruce wood & 6,7 & 81,2 & 18,3 & 0,5 & 52,0385 & 40,994 & 6,0695 & 0,2985 & 0,0995 \\
\hline 25 & Tamarack bark & 8,4 & 69,5 & 26,3 & 4,2 & 54,606 & 30,656 & 9,7716 & 0,6706 & 0,0958 \\
\hline 26 & Willow & 10,1 & 82,5 & 15,9 & 1,6 & 49,0032 & 42,7056 & 6,0024 & 0,5904 & 0,0984 \\
\hline 27 & Wood & 7,8 & 84,1 & 15,7 & 0,2 & 49,5008 & 44,0118 & 6,0878 & 0,0998 & 0,0998 \\
\hline 28 & Wood residue & 26,4 & 78 & 16,6 & 5,4 & 48,6244 & 39,6374 & 5,7706 & 0,473 & 0,0946 \\
\hline
\end{tabular}

\section{RESULTS AND DISCUSSION}

The simulation model results for the $28 \mathrm{~W} \& \mathrm{WB}$ alternatives, ranked regarding their contribution to output net power $\left(W_{\text {net }}=W_{\text {gas turbine }}-W_{\text {compressor }}\right.$ ) for 1 ton feedstock are shown in Figure 2 . This ordering is based on the net power that it is between the interval [0-400 kW/ton], values highlighting the lowest and the highest efficient options, respectively. Class 1 includes 5 wood and woody biomass gasification systems based on Land clearing wood, Fir mill residue, Forest residue, Eucalyptus bark and Alder-fir sawdust that produce the lowest amounts of output power (it is in the range of $0-100 \mathrm{~kW} / \mathrm{ton}$ ). Many of the studied W\&WB gasification systems are located in class 2 which their output power is in span of 100-200 kW per one tone of feedstock. Class 3 contains 7 wood and woody biomass gasification systems relied on Spruce wood, Pine bark, Spruce bark, Balsam bark, Hemlock bark, Poplar bark and Birch bark which generate relatively higher net power.

Obviously, the gasification system derived from Tamarack bark biomass significantly outranks all other systems from the viewpoint of power production ( $363 \mathrm{~kW} /$ ton), owing to the favorable results obtained in the performance analysis. This is mainly due to Tamarack bark has the highest percentage of carbon and hydrogen, see Figure 3. Percentage shares depicted in Figure 3 are contributions of carbon and hydrogen, oxygen, ash and nitrogen and sulphur in elemental analysis of each feedstock. Carbon and hydrogen are key elements in each biomass. So that the higher $\mathrm{C}$ and $\mathrm{H}_{2}$ content, the more carbon monoxide and hydrogen will be in the syngas and also leads to the improvement of heating value (LHV) of syngas. $\mathrm{CO}$ and $\mathrm{H}_{2}$ are combustible substances which are converted to flue gas (mainly $\mathrm{CO}_{2}$ and $\mathrm{H}_{2} \mathrm{O}$ ) through the combustion chamber. Therefore, improving LHV of syngas leads to enter gases at high temperature to the gas turbine. Raising the turbine inlet temperature ameliorates output power from that as well as more net power will be resulted. 




Figure 2. Net output power from $28 \mathrm{~W} \& W B$ gasification systems based on 1 ton feedstock (gasifier temperature $900{ }^{\circ} \mathrm{C}$ and air to fuel ratio 2)

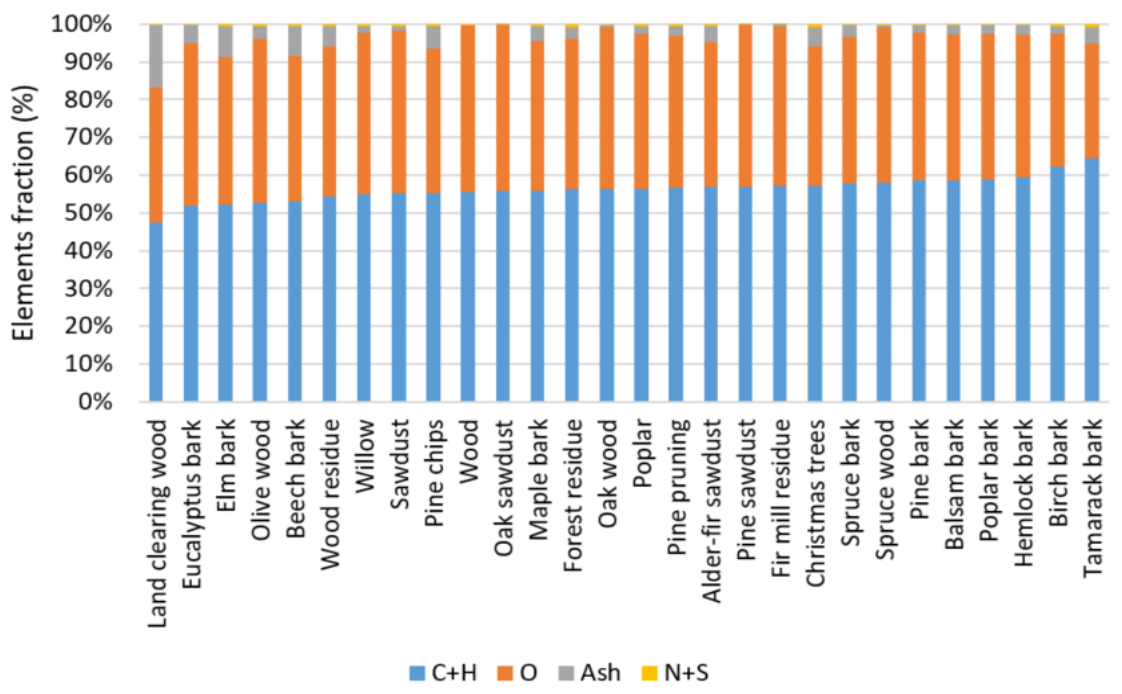

Figure 3. Percentage shares of composing elements for different W\&WBs

The impact of temperature of gasifier on power generated from the 28 wood and woody biomass gasification systems, is presented in Figure 4. The sensitivity results in Figure 4 are all at fixed conditions of 1-ton biomass input, air to fuel ratio (AFR) of 2 and temperature of gasifier in the range of $600-1500{ }^{\circ} \mathrm{C}$. Obviously for all studied W\&WBs, output power from each system is increased by growing temperature. At low temperature $\left(600{ }^{\circ} \mathrm{C}\right)$, the present carbon in the feedstock is not completely oxidized, so the syngas product can not be in an acceptable quantity. In fact, at low temperature, $\mathrm{CH}_{4}$ and unburned carbon will stay in syngas then by growing temperature much more carbon is combusted and transformed to $\mathrm{CO}$ relied on partial combustion reaction. $\mathrm{CH}_{4}$ is also converted into $\mathrm{H}_{2}$ by reverse methanation reaction. Moreover, water gas reaction (WG) moves toward $\mathrm{CO}$ and $\mathrm{H}_{2}$ production at high temperature. So, increasing the temperature of gasifier is so proper for $\mathrm{H}_{2}$ and $\mathrm{CO}$ production which causes to the improvement of lower heating value (LHV) of product gas. Then, modified LHV of syngas makes higher quality gases entering to the combustion chamber as well as high temperature gasses entering to the gas turbine. Consequently, growing TIT, turbine inlet temperature increases power output from the system. However, at a specific temperature, yield of $\mathrm{H}_{2}$ and $\mathrm{CO}$ are satisfied, both reach to an approximately fixed rates that is called the optimum temperature for the gasifier. Output power also increases in a gradual way near the optimum temperature. The optimum temperature of the down draft gasifier for W\&WB is in the range of $900-1000{ }^{\circ} \mathrm{C}$. 


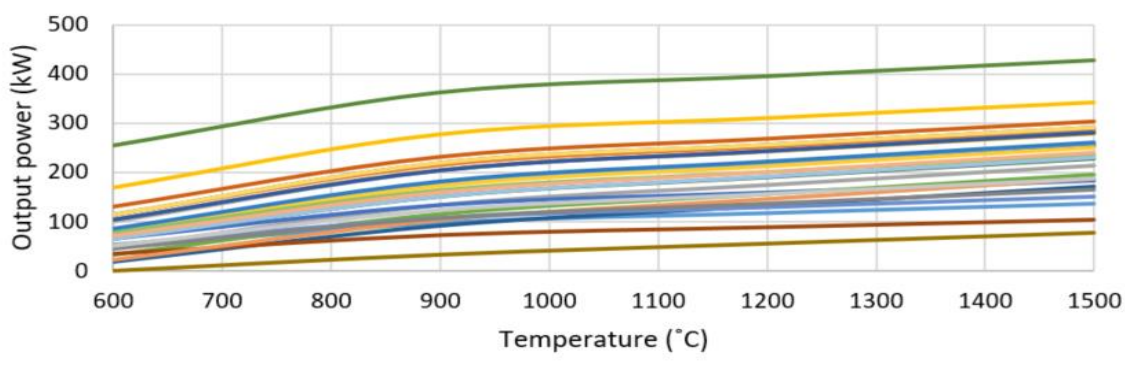

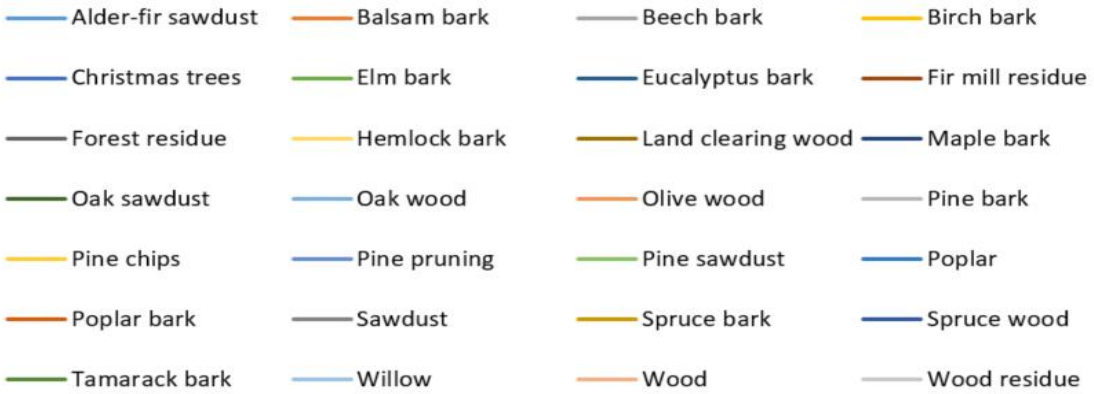

Figure 4. Impact of temperature of gasifier on power for $28 \mathrm{~W} \& \mathrm{WBs}$

Changes in the air values used in the system have a critical impact on the quality and composition of the product gas and following the generated power. The amont of air arriving the gasifier can be represented in the form of air to fuel ratio (AFR), which is the amount of air needed to burn a unit of dry biomass. The effect of AFR on power produced for the gasification systems derived from 28 wood and woody biomasses, is shown in Figure 5. In this assessment, the operating conditions are fixed on gasifier tempretare of $900{ }^{\circ} \mathrm{C}$ and 1 ton from each feedstock. The optimum AFR for W\&WB gasification is between 1,8-2. At low AFR, biomass reactions will approach to the pyrolysis, charcoal remains with corresponding energy losses. However, at much amount of AFR the additional oxygen is reacted that caused the reduce in syngas production. So, it is critical to find the proper range of AFR for W\&WB gasification.
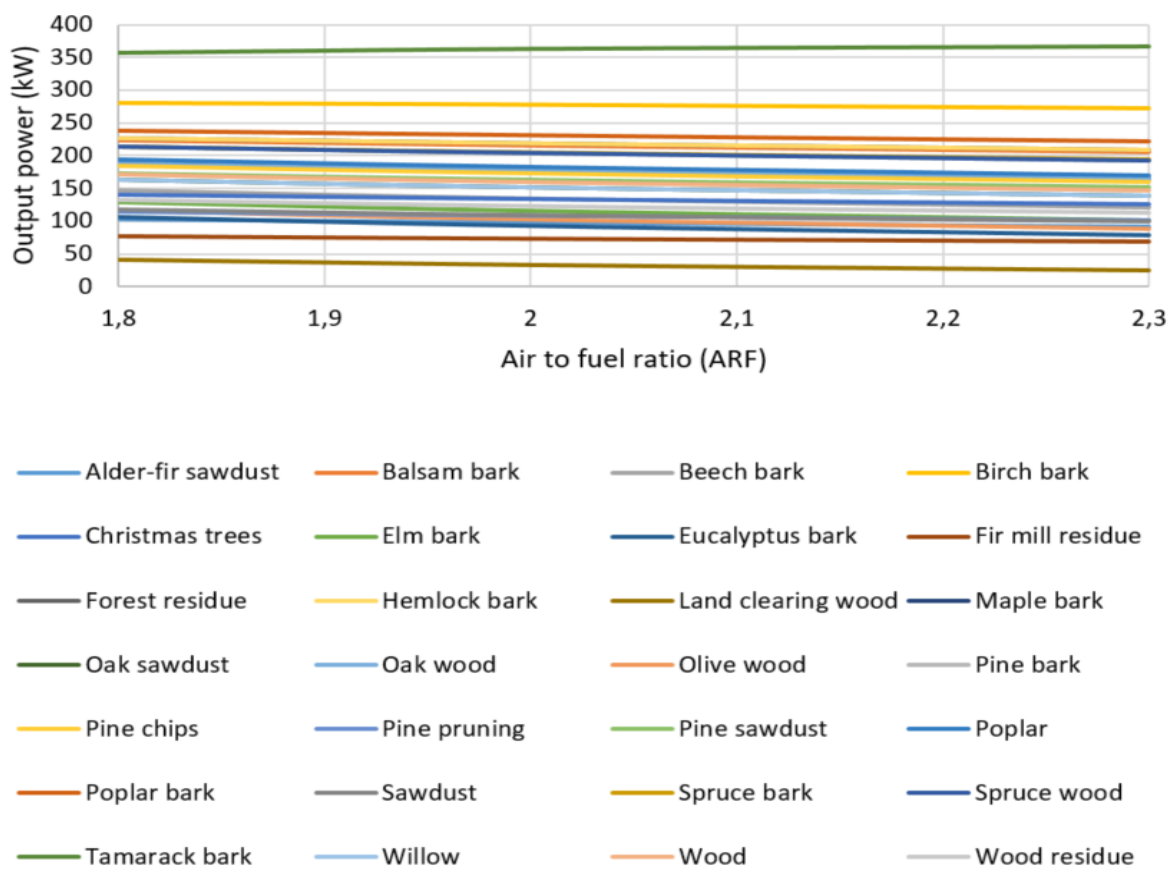

Figure 5. Effect of AFR on output power for $28 \mathrm{~W} \& \mathrm{WBs}$ 


\section{CONCLUSION}

An integrated gasification simulation model is developed containing a series of modules that models processes individually through the gasification of biomass. These processes are drying, pyrolysis, combustion and gasification linked with power generation plant (combustion chamber plus gas turbine). The established model is relied on thermodynamic equilibrium approaches and it is employed for 28 wood and woody biomasses. The studied model is practical for prediction of some outputs such as net power in a variety operating conditions like air flow rate and temperature and for different kinds of biomass materials with a specified ultimate and proximate analysis. The extablished simulation model can be a helpful tool for principally evaluation, assessment, and operation of down draft biomass gasifiers. Furthermore, the model can be employed as an assessment of various alternatives at an early stage to allow the decision-makers to carry out efficient oriented decisions.

The simulation model results for the $28 \mathrm{~W} \& \mathrm{WB}$ alternatives show that the net power produced from 1 -ton feedstock entering to the gasification system is between the interval [0-400 kW/ton] and among them, gasification system derived from Tamarack bark biomass significantly outranks all other systems by producing $363 \mathrm{~kW} /$ ton, owing to the favorable results obtained in the performance analysis. At the end, a sensitivity analysis was directed to evaluate the influence of temperature of gasifier, and AFR on output power production from each system. Extention of temperature modifies the gasifier performance, it grows the production of both $\mathrm{CO}$ and $\mathrm{H}_{2}$ that causes to higher power on output. While, growing AFR reduces $\mathrm{CO}$ and $\mathrm{H}_{2}$ production which makes in degrading of system performance.

\section{ACKNOWLEDGEMENTS}

This paper was a part of the project funded by Icelandic Research Fund (IRF), (in Icelandic: Rannsoknasjodur) and the grant number is 196458-051.

\section{REFERENCES}

[1] S. Safarian, P. Khodaparast, and M. Kateb, "Modeling and technical-economic optimization of electricity supply network by three photovoltaic systems," Journal of Solar Energy Engineering, vol. 136, no. 2, p. 024501, 2014.

[2] S. Safarian, R. Unnthorsson, and C. Richter, "Techno-economic analysis of power production by using waste biomass gasification," Journal of Power and Energy Engineering, vol. 8, no. 06, pp. 1-8, 2020.1

[3] S. Begum, M. Rasul, and D. Akbar, "A numerical investigation of municipal solid waste gasification using aspen plus," Procedia engineering, vol. 90, pp. 710-717, 2014.

[4] S. Safarian, S. Sattari, and Z. Hamidzadeh, "Sustainability assessment of biodiesel supply chain from various biomasses and conversion technologies," BioPhysical Economics and Resource Quality, vol. 3, no. 6, 2018.

[5] S. Safarian, S. Sattari, R. Unnthorsson, and Z. Hamidzadeh, "Prioritization of Bioethanol Production Systems from Agricultural and Waste Agricultural Biomass Using Multi-criteria Decision Making," Biophysical Economics and Resource Quality, vol. 4, no. 4, 2019.

[6] J. Speirs, C. McGlade, and R. Slade, "Uncertainty in the availability of natural resources: Fossil fuels, critical metals and biomass," Energy Policy, vol. 87, pp. 654-664, 2015.

[7] S. Safarian and R. Unnthorsson, "An assessment of the sustainability of lignocellulosic bioethanol production from wastes in Iceland," Energies, vol. 11, no. 6, pp. 1-16, 2018.

[8] P. Lauri, P. Havlík, G. Kindermann, N. Forsell, H. Böttcher, and M. Obersteiner, "Woody biomass energy potential in 2050," Energy Policy, vol. 66, pp. 19-31, 2014.

[9] IEA. "International Energy Association (IEA) database." http://www.iea.org/

[10] S. H. Samadi, B. Ghobadian, and M. Nosrati, "Prediction and estimation of biomass energy from agricultural residues using air gasification technology in Iran," Renewable Energy, vol. 149, pp. 1077-1091, 2020.

[11] N. Kobayashi et al., "High temperature air-blown woody biomass gasification model for the estimation of an entrained down-flow gasifier," Waste Management, vol. 29, no. 1, pp. 245-251, 2009.

[12] S. Safarian, C. Richter, and R. Unnthorsson, "Waste Biomass Gasification Simulation Using Aspen Plus: Performance Evaluation of Wood Chips, Sawdust and Mixed Paper Wastes," Journal of Power and Energy Engineering, vol. 7, no. 6, pp. 12-30, 2019.

[13] S. Safarian, R. Unnthorsson, and C. Richter, "Development of a new stoichiometric equilibrium-based model for wood chips and mixed paper wastes gasification by ASPEN Plus," in ASME International Mechanical Engineering Congress and Exposition, 2019, vol. 59438: American Society of Mechanical Engineers, p. V006T06A002.

[14] S. Safarian, R. Unnthorsson, and C. Richter, "Simulation of small-scale waste biomass gasification integrated power production: a comparative performance analysis for timber and wood waste," International Journal of Applied Power Engineering, vol. 9, no. 2, pp. 147-152, 2020.

[15] S. Safarian, R. Unnthorsson, and C. Richter, "The equivalence of stoichiometric and non-stoichiometric methods for modeling gasification and other reaction equilibria," Renewable and Sustainable Energy Reviews, vol. 131, p. 109982, 2020.

[16] P.-C. Kuo, W. Wu, and W.-H. Chen, "Gasification performances of raw and torrefied biomass in a downdraft fixed bed gasifier using thermodynamic analysis," Fuel, vol. 117, pp. 1231-1241, 2014. 
[17] P. Lestinsky and A. Palit, "Wood pyrolysis using aspen plus simulation and industrially applicable model," GeoScience Engineering, vol. 62, no. 1, p. 11, 2016.

[18] S. Rupesh, C. Muraleedharan, and P. Arun, "ASPEN plus modelling of air-steam gasification of biomass with sorbent enabled $\mathrm{CO} 2$ capture

[19] A. Gagliano, F. Nocera, M. Bruno, and G. Cardillo, "Development of an equilibrium-based model of gasification of biomass by Aspen Plus," Energy Procedia, vol. 111, pp. 1010-1019, 2017.

[20] L. P. R. Pala, Q. Wang, G. Kolb, and V. Hessel, "Steam gasification of biomass with subsequent syngas adjustment using shift reaction for syngas production: An Aspen Plus model," Renewable Energy, vol. 101, pp. 484-492, 2017.

[21] W. Doherty, A. Reynolds, and D. Kennedy, "Simulation of a circulating fluidised bed biomass gasifier using ASPEN Plus: a performance analysis," 2008.

[22] S. Begum, M. Rasul, and D. Akbar, "A numerical investigation of municipal solid waste gasification using aspen plus," Procedia engineering, vol. 90, pp. 710-717, 2014.

[23] T. Damartzis, S. Michailos, and A. Zabaniotou, "Energetic assessment of a combined heat and power integrated biomass gasification-internal combustion engine system by using Aspen Plus $®$," Fuel processing technology, vol. 95, pp. 37-44, 2012.

[24] D. Roy, S. Samanta, and S. Ghosh, "Thermo-economic assessment of biomass gasification-based power generation system consists of solid oxide fuel cell, supercritical carbon dioxide cycle and indirectly heated air turbine," Clean Technologies and Environmental Policy, vol. 21, no. 4, pp. 827-845, 2019.

[25] I.-S. Antonopoulos, et al., "Modelling of a downdraft gasifier fed by agricultural residues," Waste management, vol. 32, no. 4, pp. 710-718, 2012.

[26] S. Safarian, R. Unnthorsson, and C. Richter, "Performance analysis and environmental assessment of small-scale waste biomass gasification integrated CHP in Iceland," Energy, pp. 117268, 2020.

[27] S. Safarian, R. Unnthorsson, and C. Richter, "Techno-economic and environmental assessment of power supply chain by using waste biomass gasification in Iceland," BioPhysical Economics and Sustainability, vol. 5, pp. 7, 2020.

[28] S. Safarian, R. Unnthorsson, and C. Richter, "Simulation and performance analysis of integrated gasificationsyngas fermentation plant for lignocellulosic ethanol production," Fermentation, vol. 6, no. 3, pp. 68, 2020.

[29] K. Sun, "Optimization of biomass gasification reactor using Aspen Plus," Hogskolen i Telemark, 2015.

[30] M. B. Nikoo and N. Mahinpey, "Simulation of biomass gasification in fluidized bed reactor using ASPEN PLUS," Biomass and bioenergy, vol. 32, no. 12, pp. 1245-1254, 2008.

[31] M. S. Eikeland, R. K. Thapa, and B. Halvorsen, "Aspen plus simulation of biomass gasification with known reaction kinetic," Conf. Proceedings of the 56th Conference on Simulation and Modelling, Oct. 2015, pp. 7-9.

[32] P. Kaushal and R. Tyagi, "Advanced simulation of biomass gasification in a fluidized bed reactor using ASPEN PLUS," Renewable energy, vol. 101, pp. 629-636, 2017.

[33] N. Ramzan, A. Ashraf, S. Naveed, and A. Malik, "Simulation of hybrid biomass gasification using Aspen plus: A comparative performance analysis for food, municipal solid and poultry waste," Biomass and bioenergy, vol. 35, no. 9, pp. 3962-3969, 2011.

[34] S. V. Vassilev, D. Baxter, L. K. Andersen, and C. G. Vassileva, "An overview of the chemical composition of biomass," Fuel, vol. 89, no. 5, pp. 913-933, 2010.

[35] T. Miles, et al., "Alkali deposits found in biomass power plants: A preliminary investigation of their extent and nature," UNT Digital Library, 1995.

[36] R. W. Bryers, "Fireside slagging, fouling, and high-temperature corrosion of heat-transfer surface due to impurities in steam-raising fuels," Progress in energy and combustion science, vol. 22, no. 1, pp. 29-120, 1996.

[37] M. Theis, B.-J. Skrifvars, M. Hupa, and H. Tran, "Fouling tendency of ash resulting from burning mixtures of biofuels. Part 1: Deposition rates," Fuel, vol. 85, no. 7-8, pp. 1125-1130, 2006.

[38] M. Theis, B.-J. Skrifvars, M. Zevenhoven, M. Hupa, and H. Tran, "Fouling tendency of ash resulting from burning mixtures of biofuels. Part 2: Deposit chemistry," Fuel, vol. 85, no. 14-15, pp. 1992-2001, 2006.

[39] M. Zevenhoven-Onderwater, R. Backman, B.-J. Skrifvars, and M. Hupa, "The ash chemistry in fluidised bed gasification of biomass fuels. Part I: predicting the chemistry of melting ashes and ash-bed material interaction," Fuel, vol. 80, no. 10, pp. 1489-1502, 2001.

[40] M. Zevenhoven-Onderwater, J.-P. Blomquist, B.-J. Skrifvars, R. Backman, and M. Hupa, "The prediction of behaviour of ashes from five different solid fuels in fluidised bed combustion," Fuel, vol. 79, no. 11, pp. 1353$1361,2000$.

[41] A. Demirbas, "Combustion characteristics of different biomass fuels," Progress in energy and combustion science, vol. 30, no. 2, pp. 219-230, 2004.

[42] D. Vamvuka and D. Zografos, "Predicting the behaviour of ash from agricultural wastes during combustion," Fuel, vol. 83, no. 14-15, pp. 2051-2057, 2004.

[43] D. Vamvuka, D. Zografos, and G. Alevizos, "Control methods for mitigating biomass ash-related problems in fluidized beds," Bioresource technology, vol. 99, no. 9, pp. 3534-3544, 2008.

[44] A. Moilanen, "Thermogravimetric characterisations of biomass and waste for gasification processes," ed: VTT, 2006.

[45] A. T. Masiá, B. Buhre, R. Gupta, and T. Wall, "Characterising ash of biomass and waste," Fuel Processing Technology, vol. 88, no. 11-12, pp. 1071-1081, 2007. 
[46] M. Lapuerta, J. J. Hernández, A. Pazo, and J. López, "Gasification and co-gasification of biomass wastes: Effect of the biomass origin and the gasifier operating conditions," Fuel processing technology, vol. 89, no. 9, pp. 828-837, 2008.

[47] D. A. Tillman, "Biomass cofiring: the technology, the experience, the combustion consequences," Biomass and bioenergy, vol. 19, no. 6, pp. 365-384, 2000.

[48] A. Demirbas, "Potential applications of renewable energy sources, biomass combustion problems in boiler power systems and combustion related environmental issues," Progress in energy and combustion science, vol. 31, no. 2, pp. 171-192, 2005.

[49] X. Wei, U. Schnell, and K. R. Hein, "Behaviour of gaseous chlorine and alkali metals during biomass thermal utilisation," Fuel, vol. 84, no. 7-8, pp. 841-848, 2005.

[50] T. Damartzis, S. M. Ebrahimi Saryazdi, and A. Zabaniotou, "Energetic assessment of a combined heat and power integrated biomass gasification-internal combustion engine system by using Aspen Plus®," Fuel processing technology, vol. 95, pp. 37-44, 2012.

[51] S. Safarian, S. M. Ebrahimi Saryazdi, R. Unnthorsson, and C. Richter, "Artificial neural network integrated with thermodynamic equilibrium modeling of downdraft biomass gasification-power production plant," Energy, vol. 213, pp. 118800, 2020.

[52] J. Han et al., "Modeling downdraft biomass gasification process by restricting chemical reaction equilibrium with Aspen Plus," Energy conversion and management, vol. 153, pp. 641-648, 2017.

[53] A. J. Keche, A. P. R. Gaddale, and R. G. Tated, "Simulation of biomass gasification in downdraft gasifier for different biomass fuels using ASPEN PLUS," Clean Technologies and Environmental Policy, vol. 17, no. 2, pp. 465-473, 2015.

[54] M. Fernandez-Lopez, et al., "Simulation of the gasification of animal wastes in a dual gasifier using Aspen Plus®," Energy conversion and management, vol. 140, pp. 211-217, 2017.

[55] C. Panda, "Aspen plus simulation and experimental studies on biomass gasification," Thesis, 2012.

[56] J. F. Peters, et al., "A kinetic reaction model for biomass pyrolysis processes in Aspen Plus," Applied energy, vol. 188, pp. 595-603, 2017

[57] M. S. Eikeland and R. K. Thapa, "Stepwise analysis of gasification reactions with Aspen Plus and CPFD," International Journal of Energy Production and Management, vol. 2, no. 1, pp. 70-80, 2017.

[58] R. Liu, M. Graebner, R. Tsiava, T. Zhang, and S. Xu, "Simulation analysis of the system integrating oxy-fuel combustion and char gasification," Journal of Energy Resources Technology, pp. 1-12, 2020.

[59] F. N. Rahma, et al., "Investigation of process parameters influence on municipal solid waste gasification with CO 2 Capture via Process Simulation Approach," Int.Journal of Renewable Energy Development, vol. 10, no. 1.

[60] R. E. Moshi, Y. A. C. Jande, T. T. Kivevele, and W. Kim, "Simulation and performance analysis of municipal solid waste gasification in a novel hybrid fixed bed gasifier using Aspen plus," Energy Sources, pp. 1-13, 2020.

[61] D. Hantoko, M. Yan, B. Prabowo, H. Susanto, X. Li, and C. Chen, "Aspen Plus modeling approach in solid waste gasification," Current developments in biotechnology and bioengineering: Elsevier, pp. 259-281, 2019.

[62] S. Safarian and M. Bararzadeh, "Exergy analysis of high-performance cycles for gas turbine with air-bottoming," Journal of Mechanical Engineering Research, vol. 5, no. 2, pp. 38-49, 2012

[63] A. Demirbas, "Combustion characteristics of different biomass fuels," Progress in energy and combustion science, vol. 30, no. 2, pp. 219-230, 2004

[64] A. Demirbas, "Potential applications of renewable energy sources, biomass combustion problems in boiler power systems and combustion related environmental issues," Progress in energy and combustion science, vol. 31, no. 2, pp. 171-192, 2005.

[65] T. Madhiyanon, P. Sathitruangsak, and S. Soponronnarit, "Co-combustion of rice husk with coal in a cyclonic fluidized-bed combustor ( $\psi$-FBC)," Fuel, vol. 88, no. 1, pp. 132-138, 2009.

[66] A. Pettinau, F. Ferrara, and C. Amorino, "Combustion vs. gasification for a demonstration CCS (carbon capture and storage) project in Italy: A techno-economic analysis," Energy, vol. 50, pp. 160-169, 2013.

\section{BIOGRAPHIES OF AUTHORS}

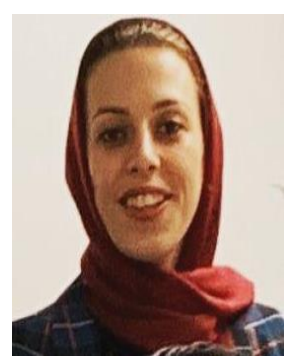

Sahar Safarian graduated Bachelor of Chemical Engineering and Master in Energy Systems Engineering. Currentlly, doing $\mathrm{PhD}$ on Waste Biomass Gasification for Energy Production in University of Iceland. Main fields are simulation, performance analysis, techno-economic and environmental assessment, gasification integrated power generation and waste to power. 


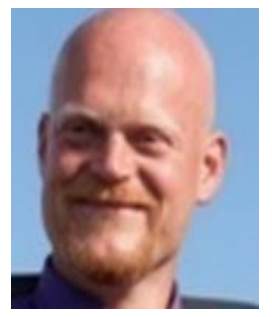

Runar Unnthorsson received the B.Sc., M.Sc., and Ph.D. Degrees in Mechanical Engineering from University of Iceland. Now he is Head of Engineering Faculty and Head of Biomass Gasification group in Department of Industrial, Mechanical and Computer Engineering at University of Iceland. Areas of expertise are renewable energy, gasification integrated power generation technology, energy efficiency, performance engineering and etc.



Christiaan Richter received B.A. in Mathematics and B.Sc. (Hons) in Applied Mathematics and Education at University of Pretoria, South Africa. Graduated M.S. in Chemical Engineering and Applied Mathematics from University of Nebraska-Lincoln and $\mathrm{PhD}$ in Chemical Engineering from Northeastern University. Curentlly, he is Professor in Faculty of Industrial Mechanical \& Computer Engineering at University of Iceland. Areas of expertise are electrocatalysis, electrochemical synthesis, biomass gasification, simulation and etc. 